\title{
Nutritional status in patients with HIV infection and AIDS
}

\author{
Marcela Stambullian ${ }^{1}$, Susana Feliu ${ }^{2,3}$ and Nora H. Slobodianik ${ }^{2,3 *}$ \\ ${ }^{1}$ Helios Salud, University of Buenos Aires, Buenos Aires, Argentina \\ ${ }^{2}$ Department of Nutrition and Food Science, University of Buenos Aires, Buenos Aires, Argentina \\ ${ }^{3}$ School of Pharmacy and Biochemistry, University of Buenos Aires, Buenos Aires, Argentina
}

The aim of this study was to evaluate the nutritional status of adults with HIV infection or with AIDS through the use of biochemical parameters. The study was performed on 43 patients (19 HIV + and 24 AIDS patients), between 26 and 44 years of age, from low and medium socioeconomic status, with access to health care services; 35 patients were under highly active antiretroviral therapy (HAART) treatment. Body weight and height were determined, and the Body Mass Index calculated $\left(\mathrm{kg} / \mathrm{m}^{2}\right)$. Blood samples were collected from fasting patients. Plasma cholesterol (total, HDL and LDL), triacylglycerol, total protein, apolipoproteins A-I and B, albumin, transthyretin, retinol binding protein, and ceruloplasmin concentrations were determined. Plasma levels of zinc, copper, and selenium were determined in a haemolysis-free sample by flame atomic absorption spectrometry. Statistical analyses were performed with the Student's t-test. AIDS patients showed changes in biochemical parameters, particularly an increase in fibrinogen and a trend to decreased transthyretin levels. These findings stress the importance of the inclusion of functional biochemical parameters in the periodic evaluation of these patients. This would allow an early assessment of the need for appropriate nutritional support, implemented along with the specific retroviral treatment. This would aim at delaying the progression of the disease, and might improve the prospects of survival and quality of life.

HIV infection: AIDS: Biochemical parameters: Serum fractions: Lipid profile: Minerals

Human immunodeficiency virus (HIV) infection is a major global health problem, and nutritional disorders are often present in HIV + /AIDS patients. Early studies demonstrated weight loss and protein depletion, findings associated with body cell mass depletion in untreated patients ${ }^{1}$. Poor nutritional status may be caused by different factors:

- inadequate nutrient intake or absorption, metabolic alterations, hypermetabolism, or a combination of these;

- alteration of the gastrointestinal tract;

- drug-nutrient interactions.

Anorexia related to the psychological processes provoked by the pathology (mainly social isolation), biochemical changes, including an increase in the activity of the cytokines, a diverse drug intake, physical inactivity, and opportunistic diseases also lead to a decrease in food intake ${ }^{2-5}$.

Since the appearance of highly active antiretroviral therapy (HAART), a lower incidence of malnutrition, and an improvement of the survival and immunological functions of infected patients has been observed. However, this highly effective antiretroviral therapy is associated with lipodistrophy, related, in turn, to insulin resistance and its metabolic complications, such as impaired glucose tolerance, diabetes, and hypertriglyceridemia $^{1,6,7}$.

The importance of nutritional support, in addition to the antiretroviral therapy in HIV + /AIDS patients, has been accepted. Nutritional support is needed to maintain optimum nourishment during the symptomatic period, in order to prevent further deterioration of the nutritional status during acute episodes of infection, and to improve the nutritional status during the stable symptom-free period $^{8,9}$. Since 1989, the American Dietetic Association emphasised that nutrition intervention and education should be part of the health care provided to individuals infected with HIV, and they should be implemented at all stages of the disease ${ }^{10}$. It is also advocated that nutritional intervention should be applied early and individually, with periodic and constant screening ${ }^{11}$. Some authors have pointed out that nutritional deficiency may influence the biological gradient and the natural course of the AIDS infection ${ }^{12}$.

International literature considers that biochemical evaluation in AIDS patients must include at least serum levels of albumin, transferrin, total protein, and cholesterol, blood haemoglobin content and haematocrit. It is also considered that the depletion of some of these is indicative of protein deficiency or anaemia, respectively. On the other hand, routine indicators, such as the total number of lymphocytes and delayed hypersensitivity skin tests, are not useful as indices of nutritional state, due to the impact of the disease on immunological markers ${ }^{13}$. Moreover, some authors indicate that nutritional assessment of these patients should include a measurement of body composition, and analyses of nutritional parameters, including albumin, transthyretin, and C-reactive $\operatorname{protein}^{14}$. 
The aim of this study was to evaluate the nutritional status of adults infected with HIV or with AIDS through the examination of their biochemical profile.

\section{Methods and materials}

Body weight and height were determined, and the BMI $\left(\mathrm{kg} / \mathrm{m}^{2}\right)$ calculated in 43 patients $(19 \mathrm{HIV}+$ and 24 AIDS patients) between 26 and 44 years old, who attended Helios Salud, a health centre specialised in AIDS management. Blood samples were collected from fasting patients; 35 patients received HAART. $89 \%$ presented CD4 + blood cell counts of $>200$ cells $/ \mathrm{ml}$ and $60-75 \%$ showed viral charges lower than 50 copies/ml. Plasma cholesterol, HDL and LDL cholesterol, triacylglycerol, total protein, apolipoproteins A-I and B (ApoA-I and ApoB) and fibrinogen concentrations were determined. Specific plasma proteins of potential utility in nutrition studies, including albumin, transthyretin, retinol binding protein (RBP) and the acute phase reactant ceruloplasmin were also determined. Total protein content was determined by the Biuret method, and specific proteins by quantitative radial immunodiffussion on plates (Diffuplate, Biocientifica SA, Argentina and Binding Site, UK). Results were compared to reference values ${ }^{15-17}$.

Total cholesterol, HDL and triacylglycerol concentrations were determined by enzymatic-colorimetric methods, and LDL was calculated with Friedwald's equation (LDLcholesterol $=$ total cholesterol - triacylglycerols $/ 5+$ HDLcholesterol). Reference values for total cholesterol, HDL, LDL, triacylglycerolsglycerides, were taken from the current guidelines for handling dislipidaemia ${ }^{18}$.

Plasma levels of zinc $(\mathrm{Zn})$, copper $(\mathrm{Cu})$, and selenium $(\mathrm{Se})$ were determined in haemolysis-free plasma by flame atomic absorption spectrometry. For each mineral, a calibration curve was performed, using commercial standards ${ }^{19,20}$. The $\mathrm{Cu} / \mathrm{Zn}$ ratio was calculated, and compared with reference values $^{21}$. Statistical analyses were performed with the Student's t-test.The study was approved by the Ethics Committee of the University of Buenos Aires, and all participants gave written consent before recruitment.

\section{Results}

Table 1 shows the BMI, total protein concentration, and plasma levels of albumin, transthyretin, RBP, ceruloplasmin. No significant differences were observed in BMI, total protein concentration and plasma levels of albumin, transthyretin, RBP and ceruloplasmin, between HIV + and AIDS patients. Table 2 shows the lipid profile, ApoA-I, ApoB and fibrinogen in the patients. Fibrinogen levels from the AIDS patients were higher than those of the HIV + group. No statistical differences between the groups were observed in other biochemical parameters. Regarding the minerals status, there were no statistical differences in plasma $\mathrm{Cu}, \mathrm{Zn}$, and $\mathrm{Se}$ levels or in the $\mathrm{Cu} / \mathrm{Zn}$ ratio between the HIV + and AIDS groups. $\mathrm{Zn}(\mu \mathrm{g} / \mathrm{ml}): 2.04(0.42)$ vs. $2.20(0.64) ; \mathrm{Cu}(\mu \mathrm{g} / \mathrm{ml})$ $1.77(0.35)$ vs. $1.83(0.28)$; Se $(\mu \mathrm{g} / \mathrm{l}): 47.6$ (18.3) vs. 43.7 (13.7); $\mathrm{Cu} / \mathrm{Zn}$ ratio: $0.91(0.31)$ vs. $0.87(0.20)$. Both groups showed plasma $\mathrm{Zn}$ and $\mathrm{Cu}$ levels within the highest reference values. About $70 \%$ of the patients had plasma Se concentrations which were below $60 \mu \mathrm{g} / \mathrm{l}$.

\section{Discussion}

HIV-infected and AIDS patients showed albumin levels within the reference range. Different investigators have demonstrated that the levels of albumin, transthyretin, and C-reactive protein are predictors of survival ${ }^{4,14,21,22}$. Short-lived proteins are very promising in the evaluation of the nutritional status ${ }^{22}$. However, metabolic disorders caused by stress can also affect their concentration ${ }^{23-25}$. In this study, we observed that $50-60 \%$ of HIV + /AIDS patients presented plasma RBP levels close to the highest reference values, and $10 \%$ of AIDS patients showed transthyretin values within the highest reference values. This behaviour was also described by Lopez Hellin et al. ${ }^{26}$ in a group of postsurgical patients with high levels of stress. Only two patients with AIDS and one $\mathrm{HIV}+$ patient showed transthyretin values lower than $20.0 \mathrm{mg} / \mathrm{dl}$, this value is associated with protein deficiency ${ }^{22,24}$. In contrast, previous results performed on forty-five children with AIDS, diagnosed according to the criteria of the Centers for Disease Control and Prevention, showed lower levels of transthyretin and RBP than laboratory reference values ${ }^{27}$. Around $40 \%$ of HIV + and AIDS patients presented ceruloplasmin levels above $65 \mathrm{mg} / \mathrm{dl}^{15}$. It is interesting to remark that AIDS patients with transthyretin levels above $40 \mathrm{mg} / \mathrm{dl}$ presented ceruloplasmin concentrations over reference values, so this plasma fraction would be performing the role of acute phase protein. Fibrinogen levels were significantly higher in AIDS patients while total cholesterol, triacylglycerol, LDL and Apo B tended to be higher in the HIV + patients, but the differences between groups did not reach statistical significance. These changes were described in several reports as complications related to the antiretroviral medication, especially regarding the levels of triacylglycerols and very low density lipoproteins (VLDL) ${ }^{28}$.

The changes of fibrinogen in this study supports previous studies on HIV + /AIDS infants (M.S. Feliu, unpublished results), and stress the importance to include fibrinogen in the periodic nutritional monitoring of these patients. The global analysis of the results shows an alteration in the lipid profile of HIV + /AIDS patients, and emphasises the need to

Table 1. BMI, and concentrations of total and specific plasma proteins in HIV + and AIDS patients

\begin{tabular}{lcccccc}
\hline Group & BMI $\left(\mathrm{kg} / \mathrm{m}^{2}\right)$ & Total protein $(\mathrm{g} / \mathrm{dl})$ & Albumin $(\mathrm{g} / \mathrm{dl})$ & Transthyretin $(\mathrm{mg} / \mathrm{dl})$ & RBP $(\mathrm{mg} / \mathrm{dl})$ & Ceruloplasmin $(\mathrm{mg} / \mathrm{dl})$ \\
\hline HIV + & $23.8(3.8)$ & $8.69(0.51)$ & $4.50(0.4)$ & $33.0(6.3)$ & $8.29(2.6)$ & $64.2(18.2)$ \\
AIDS & $25.9(4.5)$ & $8.78(0.96)$ & $4.54(0.4)$ & $30.9(6.7)$ & $8.40(1.5)$ & $70.6(15.2)$ \\
\hline
\end{tabular}

Data are mean (SD).

RBP, Retinol binding protein. 
Table 2. Plasma lipid profile, and concentrations of apolipoproteins $A-I$ and $B$ and fibrinogen in HIV + and AIDS patients

\begin{tabular}{|c|c|c|c|c|c|c|c|}
\hline Group & Total cholesterol (mg/dl) & $\mathrm{HDL}(\mathrm{mg} / \mathrm{dl})$ & LDL (mg/dl) & Triglycerides (mg/dl) & ApoA-I (mg/dl) & ApoB (mg/dl) & Fibrinogen (mg/dl) \\
\hline HIV + & $174.3(24.9)$ & $47.0(12 \cdot 2)$ & $100 \cdot 8(25 \cdot 2)$ & $108 \cdot 7(46 \cdot 2)$ & $256.8(67.5)$ & $162 \cdot 7$ (52.2) & $392 \cdot 9$ (120.2) \\
\hline AIDS & $197.4(46.7)$ & $44.4(10.2)$ & $114.6(42.0)$ & $220.1(159.8)$ & $278.3(58.4)$ & $182.5(42.1)$ & $475.8(149.5)^{\star}$ \\
\hline
\end{tabular}

Data are mean (SD)

${ }^{\star}$ Significantly different from HIV + at $P<0.05$.

design appropriate nutritional treatments. This would allow an early evaluation of cardiovascular risk and the implementation of therapeutic guidelines, along with the specific retroviral treatment and adequate food selection, to exert a positive effect on plasma lipids, an important factor of cardiovascular risk $^{29,30}$

On the other hand, Treitinger et al. observed a decrease in the HDL-fraction, triacylglycerol, and albumin levels with an increase in haptoglobin concentration, as indicators of the progression of the disease in HIV + -infected patients ${ }^{31}$.

Several investigators have pointed out that a $\mathrm{Cu} / \mathrm{Zn}$ ratio $>1.0$ is associated with an increase in mortality ${ }^{32}$. In our study, about $30 \%$ of AIDS patients showed a $\mathrm{Cu} / \mathrm{Zn}$ ratio higher than 1 while $21 \%$ of HIV infected patients did. Moreover, these patients suffered deterioration of the immune system, indicated by the lower number of CD4 + lymphocytes. This would be in agreement with Lai et al. ${ }^{32}$, who proposed that the $\mathrm{Cu} / \mathrm{Zn}$ ratio would be a useful predictor of survival in HIV infection. Besides,.Moreno et al. ${ }^{32}$ indicate that serum copper determination would be a helpful marker in the progression of the infection towards AIDS, and in other chronic infectious diseases.

Serum zinc levels in the studied individuals were within or over normal values; this finding agrees with a preliminary study performed in HIV + /AIDS children, but differs from data reported by other authors for adult patients, which indicated a decrease in serum $\mathrm{Zn}$ concentration ${ }^{33,34}$. It is important to remark that Wellinhausen et al. ${ }^{35}$ also demonstrated a decrease in $\mathrm{Zn}$ levels in $23 \%$ of a HIV + -infected population, which is in agreement with our results ${ }^{35}$. Due to the importance of $\mathrm{Zn}$ to the immune system, the assessment of this mineral is very important in order to optimise the results of the nutritional treatment and drug therapy and its incorporation into the diet must be considered.

In addition, $65-70 \%$ of the studied population showed decreased plasma Se levels when compared to reference values; this fact is in agreement with international literature ${ }^{36,37}$. The same observation was made in a preliminary study on infected children ${ }^{34}$. Different authors indicate a sharp relationship between selenium deficiency and the deterioration of the immune system; they consider this biochemical parameter as an independent predictor of survival for patients infected with $\mathrm{HIV}^{35,36}$. Our results stress the importance of analyzing the possible effect of the addition of selenium in the prevention and treatment of AIDS-related pathologies.

Bogden et al. $^{37}$ have reported that depression of the nutritional status begins in the first stages of HIV-1 infection, which can contribute to the progression of the disease.

Our preliminary study, performed on HIV + and AIDS patients belonging to low and medium socioeconomic groups, with access to health care services, shows some differences in some biochemical parameters: an increase in fibrinogen and a trend to decreased transthyretin levels. Therefore, the nutritional status of infected patients is different at different stages of the disease. Moreover, these findings support previous studies on HIV + /AIDS-infected infants, and emphasise the importance of incorporating functional biochemical parameters in the periodic nutritional assessment of these patients ${ }^{34,38}$. This would allow an early evaluation of the nutritional status, and the assessment of an appropriate tailored nutritional support, implemented along with the specific retroviral treatment. This would aim at delaying the evolution of the disease, and might improve the prospects of survival and quality of life of these patients.

\section{Conflict of interest statement}

This study was funded by the University of Buenos Aires (B-060). The authors have no conflict of interests to declare. The manuscript is in partial fulfillment of the Doctor's Degree of MS, fellow of University of Buenos Aires. The article was discussed and co-written by all authors (MS, SF, NHS).

\section{References}

1. Kotler DP (2000) Nutritional alterations associated with HIV infection. J Acquir Immune Defic Syndr 25, S81-S87.

2. Johnson JA, Albu JA, Engelson ES, Fried SK, Inada Y, Ionescu G \& Kotler DP (2004) Increased pro-inflammatory cytokine activity in HIV-infected subjects with lipodystrophy. Am J Physiol Endocrinol Metab 286, E261-E271.

3. Elbein RC (1995) Nutrition and HIV infection: a continuun of care. J Am Pediatr Med Assoc 8, 434-438.

4. Melchior JC, Niyongabo T, Henzel D, Durack-Brown I, Henri SC \& Boulier A (1999) Malnutrition and wasting, immunodepression and chronic inflammation survival as independent predictors in HIV-infected patients. Nutrition 15, 865-869.

5. Wanke CA, Falutz JM, Shevitz A, Phair JP \& Kotler DP (2002) Clinical evaluation and management of metabolic and morphologic abnormalities associated with human immunodeficiency virus. Clin Infect Dis 34, 248-259.

6. Shevitz A, Wanke CA, Falutz J \& Kotler DP (2001) Clinical perspectives on HIV-associated lipodystrophy syndrome: an update. AIDS 15, 1917-1930.

7. Chen D, Misra A \& Garg A (2002) Clinical review 153: Lipodystrophy in human immunodeficiency virus-infected patients. $J$ Clin Endocrinol Metab 87, 4845-4856.

8. Sherlekar S \& Udipi SA (2002) Role of nutrition in the management of HIV infection /AIDS. J Indian Med Assoc 100, 385-390.

9. Polsky B, Kotler D \& Steinhart C (2001) HIV-associated wasting in the HAART era. Guidelines for assessment, diagnosis, and treatment. AIDS Patient Care 15, 411-423.

10. Position of the American Dietetic Assoc: nutrition intervention in the treatment of HIV (1989) J Am Diet Assoc 92, 477-478. 
11. Fajardo Rodriguez A \& Lara del Rivero-Vera CM (2001) Nutritional intervention in HIV + /AIDS: practical guide for its implementation and follow-up. Gac Med Mex 137, 489-500.

12. Chandra RK 1990 McCollum Award lecture (1991) Nutrition and immunity: lessons from the past and new insights into the future. Am J Clin Nutr 53, 1087-1091.

13. McCorkindale C, Dybevik K, Coulston AM \& Sucher KP (1990) Nutritrional status of HIV-infected patients during the early stages disease. J Am. Diet Assoc 90, 1236-1240.

14. Salomon J, de Truchis P \& Melchior JC (2002) Body composition and nutritional parameters in HIV and AIDS patients. Clin Chem Lab Med 40, 1329-1333.

15. Mancini G, Carbonara AO \& Heremans GF (1965) Immunochemical quantitaiton of antigen by single radial immunodiffusion. Immunochemistry 2, 235-254.

16. Feliu MS \& Slobodianik NH (1993) Valores de referencia de fracciones séricas específicas en adultos. Acta Bioquim Clin Latinoam XXVII, 519-520.

17. Weisstaub A, Feliu MS \& Slobodianik NH (1994) Valores de referencia de proteína transportadora de vitamina A (RBP), en adultos. Acta Bioquim Clin Latinoam XXVIII, 447-448.

18. Kavey RE, Daniels SR, Lauer RM, Atkins DL, Hayman LL \& Taubert K (2003) American Heart Association - American Heart Association guidelines for primary prevention of atherosclerotic cardiovascular disease beginning in childhood. J Pediatr 142, 368-372.

19. Analytical methods. Flame atomic absorption spectrometry (1989) Varian Australia Pty Ltd. Publication No. 85-100009-00.

20. For Analytical methods graphite tube atomizers (1989) Publisher: E. Rothery. Varian Australia Pty Ltd. Publication No. 85- 100848-00.

21. Lockitch G, Halstead A \& Wadsworth L (1988) Age and sex specific pediatric reference intervals for Zinc, Copper, Selenium, iron and vitamins $\mathrm{A}$ and $\mathrm{E}$ and related proteins. Clin Chem 34, 1625-1627.

22. Niyongabo T, Melchior JC, Henzel D, Bouchaud O \& Larouze B (1999) Comparison of methods assessing nutritional status in HIV infected-adults. Nutrition 15, 740-743.

23. Slobodianik Nora H (2003) Metabolismo proteico. In Fundamentos de valoración nutricional y composición corporal, pp. 41-50 [Daniel H. De Girolami, editor]. Buenos Aires, Argentina: El Ateneo.

24. Ingengleek Y \& Young V (1994) Transthyretin (Prealbumin) in health and disease: Nutritional Implications. Annu Rev Nutr 14, 495-533.

25. Bernstein L \& Pleban W (1996) Prealbumin in Nutrition Evaluation. Nutrition 12, 255-259.
26. López Hellin J, Baena-Fustegueras JA, Schwartz-Riera S \& Garcia -Arumi E (2002) Usefulness of short-lived proteins as nutritional indicators in surgical patients. Clin Nutr 21, 119-125.

27. Slobodianik N, Pallaro A, Río ME, Barbeito S, Strasnoy I, Franchello A, Casella E, Torales ME, Giraudi V \& Ramos O (1996) Prealbumin, Retinol-Binding Protein and Total Salivary IgA in children with AIDS. Clinical Chemistry 42, 471-472.

28. Carr A \& Cooper D (2000) Adverse effects of antiretroviral therapy. The Lancet 356, 1423-1429.

29. Myers G, Rifai N, Tracy R, et al. (2004) CDC/AHA Workshop on Markers of Inflammation and Cardiovascular Disease. Circulation 110, 545-549.

30. Stein J (2005) Managing Cardiovascular Risk in Patients with HIV Infection. JAIDS 38, 2, 115-123.

31. Treitinger A, Spada C, da Silva LM, Hermes EM, Amaral JA \& Abdalla DS (2001) Lipid and acute-phase protein alterations in $\mathrm{HIV}+-1$ infected patients in the early stages of infection: correlation with CD4 + lymphocites. Braz J Infect Dis 5, 192-199.

32. Lai H, Lai S, Shor-Posner G, Ma F, Trapido E \& Baum MK (2001) Plasma zinc, copper, copper:zinc ratio and survival in a cohort of HIV-1 infected homosexual men. $J$ Acquir Immune Defic Syndr 27, 56-62.

33. Moreno T, Artacho R, Navarro M, Perez A \& Ruiz López MD (1998) Serum copper concentration in HIV-infected patients and relationships with other biochemical indices. Sci Total Environ 217, 21-26.

34. Pallaro A, Barbeito S, Strasnoy I, Franchello A, Giraudi V, Ramos O \& Slobodianik NH (1998) Niveles de Zinc y Selenio en un grupo de niños HIV + . Estudio preliminar. Acta Bioquim Clin Latinoam XXXII, 555-557.

35. Wellinghausen N, Kern Wv, Jochle W \& Kern P (2000) Zinc serum level in human immunodeficiency virus-infected patients in relation to immunological status. Biol Trace Elem Res 73, 139-149.

36. Baum MK, Shor-Posner G, Lai S, Zhang G, Lai H, Fletcher MA, Sauberlich H \& Page JB (1997) High risk of HIV-related mortality is associated with selenium deficiency. $J$ Acquir Immune Defic Syndr Hum Retrovirol 15, 370-374.

37. Bogden JD, Kemp FW, Hans S, et al. (2000) Status of selected nutrients and progression of human immunodeficiency virus type 1 infection. Am. J Clin Nutr 72, 809-815.

38. Pallaro A, Barbeito S, Strasnoy I, Franchello A, Giraudi V, Ramos O \& Slobodianik (2000) Efecto del apoyo nutricional sobre el perfil bioquímico de niños HIV + . Estudio preliminar. Bioquímica y Patología Clínica 64, 5-7. 